\title{
MASTERING
}

\section{ENGLISH AS A FOREIGN LANGUAGE}


Accounting

Arabic

Astronomy

Australian History

Background to Business

Banking

Basic English Law

Basic Management

Biology

British Politics

Business Communication

Business Law

Business Microcomputing

Catering Science

Catering Theory

Chemistry

COBOL Programming

Commerce

Computer Programming

Computers

Data Processing

Economic and Social History

Economics

Electrical Engineering

Electronics

English as a Foreign Language

English Grammar

English Language

English Literature

Financial Accounting

French

French 2

German

Hairdressing

Italian

Italian 2

Japanese

Keyboarding

Marketing

Mathematics

Modern British History

Modern European History

Modern World History

Nutrition

Office Practice

Pascal Programming

Physics

Practical Writing

Restaurant Service

Social Welfare

Sociology

Spanish

Spanish 2

Statistics

Statistics with your Microcomputer

Study Skills

Typewriting Skills

Word Processing 


\section{MASTERING}

\section{ENGLISH AS A}

\section{FOREIEN LANEUAAEE}

ROB NOLASCO

Editorial Consultant

B E T T Y P A R R

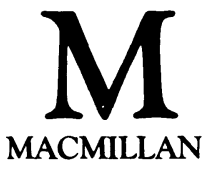


(C) R. Nolasco 1990

All rights reserved. No reproduction, copy or transmission of this publication may be made without written permission.

No paragraph of this publication may be reproduced, copied or transmitted save with written permission or in accordance with the provisions of the Copyright Act 1956 (as amended), or under the terms of any licence permitting limited copying issued by the Copyright Licensing Agency, 33-4 Alfred Place, London WC1E 7DP.

Any person who does any unauthorised act in relation to this publication may be liable to criminal prosecution and civil claims for damages.

First edition 1990

Published by

MACMILLAN EDUCATION LTD

Houndmills, Basingstoke, Hampshire RG21 2XS

and London

Companies and representatives

throughout the world

Nolasco, Rob

Mastering English as a Foreign Language.-

(Macmillan Master Series)

1. Spoken English language

I. Title II. Parr, Betty

428.3

ISBN 978-0-333-45878-5

ISBN 978-1-349-20872-2 (eBook)

DOI 10.1007/978-1-349-20872-2

ISBN 978-0-333-45879-2 


\section{CONTENTS}

Series Editor's Preface

xi

Introduction: How to use this book

xii

I. TEACHING UNITS

1 Arriving in Britain

Topic - Brigitte arrives in Britain

Structures - Present of verb to be; where from + nationality, this/that

Explanations - to be; this/that; nationality

Background - Arriving in Britain; money

Aim - Learn to ask and answer personal questions

Writing - Simple personal description

2 I have a reservation here

Topic - Brigitte checks into a hotel and meets Hank

Structures - Have got ... ?; What time is it ...?

Explanations - Time; introductions; have got

Background - B \& B; 24 hour clock; VAT

Aim - Learn to meet strangers and make an enquiry

Writing - Completing a form

3 Where is the tube station?

Topic - Brigitte begins to find her way in town

Structures - Where's . . ?; is there ... and are there?; it's + preposition; for expression of distance

Explanations - Imperatives; prepositions; directions; the; there is/there are

Background - London

Aim - Learn to get and receive information about locations

Writing - Simple instructions on how to get from A to $\mathrm{B}$ 
4 I'd like to change some money

Topic-Brigitte goes to the bank and to a shop with Hank

Structures - Would like; to be looking for; one; much/many; present continuous

Explanations - l'd like to; much/many some; present continuous; one Background - Changing money; going shopping Aims - Learn to get what is wanted Writing - Drawing up a list

5 Could you take our order; please?

Topic - Brigitte has a meal in a restaurant with Hank

Structures - Like; a little/a few; I'll have; Could you ....?

Explanations - Little/few;would; can/could; will Background - Meals

Aim - Learn to express likes and dislikes; make polite requests

Writing - Describing a meal

6 What sort of things does he like?

Topic - Brigitte meets Margaret in a pub

Structures - Present simple; was, were;

Explanations - The present simple; present simple $v s$ present continuous

Background - Pubs

Aim - Learn to find out about other people and what they do

Writing - An initial letter to a pen friend

7 Nobody understood me

Topic - Margaret, Brigitte and Laurent talk about their experiences

Structures - Simple past narrative; question forms; sequencing

Explanations - Past simple

Background - National Gallery/Chinatown/Covent Garden; shops and shopping areas Aim - Learn to talk/write about their experiences Writing - Telling a story 
8 Where shall we go?

Topic - Brigitte and Margaret make plans for a weekend

Structures - Let's . .; shall we ... ?; will; going to Explanations - Present continuous future; 'Going to' future; Shall/will future; any

Background - The pleasures of life - English style Aim - Learn to make future plans; arrange to meet Writing - An informal invitation

9 We could see The Phantom of the Opera

Topic - Brigitte, Laurent and Hank decide to go to the theatre

Structures - Could; might; first conditional

Explanations - May and might; could (do), if

+ future

Background - West End theatreland

Aim - Learn to discuss alternative plans

Writing - A note to confirm an arrangement

10 As I was walking down Oxford Street

Topic - Brigitte tells Margaret about an incident in Oxford Street

Structures - Past continuous; adverbs

Explanation - Past continuous; stop + infinitive vs

stop + -ing; adverbs

Background - Shoplifting

Aim - Learn to tell a personal anecdote

Writing - Simple narrative in a personal letter

11 What's he like?

Topic - Margaret tells Brigitte about her cousin in Cambridge

Structures - Present perfect; adjectives

Explanation - Present perfect; since vs for

Background - Newspapers

Aim - Learn to describe people

Writing - Simple personal description

12 I'm sorry I'm late ...

Topic - Brigitte goes on a train journey; she apologises to Peter about being late 
Structures - I've just . . .; I'm sorry; third

conditional

Explanations - Third conditional; if + present +

future

Background - Intercity transport

Aim - Learn to make excuses

Writing - A letter of apology

13 That's King's College on the left

Topic - Peter takes Margaret on a tour of

Cambridge

Structures - Have you ever; adjectives;

comparisons; passive

Explanations - The passive; 16th Century; have you ever?

Background - University life

Aim - Learn to follow simple tours

Writing - Describing a building

14 What's up? Are you feeling well?

Topic - Hank has to go to the doctor

Structures - What's the matter? ; Why don't

you ....?

Explanation - Advice

Background - Health

Aim - Learn to give advice, suggestions and

sympathy; make appointments

Writing - Giving advice

15 I'm afraid I've got a complaint

Topic - Brigitte complains about her room

Structures - Must; I'm afraid; I'd rather

Explanations - Must; complaints; apologies

Background - How to put things right

Aim - Learn to discuss problems and complain

Writing - A simple letter of complaint

16 In the old days we used to ...

Topic - Brigitte and Margaret meet Margaret's grandmother 
Structures - Used to; had to; weren't allowed to; past perfect

Explanation - Used to; past perfect

Background - Housing

Aim - Learn to talk about the way things were

Writing - Describing childhood

17 How to make Yorkshire Pudding

Topic - Brigitte learns how to make Yorkshire pudding

Structures - Imperative forms; passive; sequencing

Explanation - Be used to; imperatives

Background - The regions of Britain

Aim - Learn to give and receive instructions

Writing - Instructions

18 What did she say?

Topic - Laurent tells Brigitte about a telephone call home

Structures - Reported speech

Explanations - Direct/indirect speech; reporting questions

Background - Education

Aim - Learn how to report simple conversations

Writing - Reporting a conversation

19 If I were you ...

Topic - Brigitte and Laurent meet some English

people who are planning a holiday abroad

Structures - Ought; should if I were you

Explanations - Ought; should

Background - Tourism in Britain; souvenirs

Aim - Learn to give advice to potential

visitors

Writing - Letter to potential visitors

20 Next year we could meet in Germany

Topic - Brigitte and Margaret plan for the future as they say farewell

Structures - Could; may; question tags

Explanations - Question tags 
Background - A British holiday

Aims - Learn to express possibility,

probability and future intentions

Writing - A letter of thanks

II. REFERENCE MATERIAL

207

Key to Exercises

209

Essential Vocabulary

233

Grammar Reference Section

336

Guide to Pronunciation

270

Bibliography and Sources of Information

276 


\section{SERIES EDITOR'S PREFACE}

Mastering English as a Foreign Language, like all the other language courses in this series, is designed for adults working with or without a teacher. It is, however, not for beginners, but for students who already have a basic knowledge of English and wish to improve their command of the spoken and written language so that they may use it effectively in everday life. The book is accompanied by a cassette, which is an important element in the programme.

Though all the language skills are practised, the emphasis is on the spoken language of ordinary, educated people. The occasional introduction of American English is intended as a reminder of the wide spread use of the language, but it is not meant to serve as an alternative model.

The ground plan of the Course is similar to that in the other first-stage language books of the series. Each chapter begins with dialogues based on everyday situations, and this material provides the context for all the teaching. Explanations of vocabulary and grammar are followed by exercises graded at two levels. Exercises under $A$ are based on the language of the dialogues but those under $B$ go further and provide additional practice for students who want it. They can also assess their progress with the help of the key to the exercises, placed in the reference section at the end of the book. Each chapter contains background information, so that some insight may be obtained into different aspects of everyday life in England. In a book of this size, it is unfortunately impossible to include details of the other countries in the United Kingdom.

The reference section contains, in addition to the key to the exercises, a guide to pronunciation and a summary of the grammar introduced throughout the book. There is a short bibliography as well as a list of useful addresses. It is hoped that the student will find this carefully planned course a helpful aid to study, which will bring the pleasure of an increasing mastery of the English language, with all its vigour and variety. 


\section{INTRODUCTION:}

\section{HOW TO USE THIS BOOK}

This course is for students of English as a Foreign Language. It is intended for those who speak some English but feel that it is now time to master the English used in everyday communication.

The story of a girl's visit to England provides the framework for a rapid revision of the main structures and vocabulary of English. There are practice exercises, background information about Britain, explanations of vocabulary and grammar, and a reference section. The reference section includes a Grammar Reference Section, a Guide to Pronunciation and an Answer Key. The course also comes with a cassette, a most important element in the programme.

\section{CHAPTER STRUCTURE}

Each chapter starts with a series of dialogues.

Each dialogue is followed by explanations of:

1 Useful expressions and vocabulary

2 The main grammar points in the chapter

Next there is a simple background text about British life.

Then there are exercises.

The exercises in Section A are based on the dialogues in the chapter.

The exercises in Section B provide further practice, at a slightly more difficult level.

There is a short writing task at the end of each chapter.

Here are some ideas on how to use the different sections of the book:

\section{GUIDE TO PRONUNCIATION}

This is a summary of the main sounds of English.

Try to listen to this as soon as you can.

Listen and repeat, using your pause button where necessary. 


\section{DIALOGUES}

These provide examples of spoken English.

If possible listen to the dialogue before you read the text.

This will help your listening.

When you have read the explanations and finished the exercises repeat the dialogues as you listen to the tape, using the pause button to give you time to practise.

\section{EXPLANATIONS}

Try to see if you can understand the vocabulary and expressions without using a dictionary.

Learn the key expressions and use them if you get the chance.

Some learners find grammar explanations very helpful, others do not. Don't worry if you find the explanations difficult. The important thing is to get the exercises right.

\section{BACKGROUND}

The background texts give information about life in England.

When you read them try to use your knowledge of the world and your own country to help you understand them.

Underline any useful expressions and learn them.

The background texts will help your reading skills.

It is not possible, in a book of this size, to include any detailed references to the other parts of the United Kingdom.

\section{EXERCISES}

If you are short of time concentrate on Section A.

Use the Answer Key to check your exercises.

If writing English is important to you then try the writing tasks.

In some cases there are model answers.

\section{GRAMMAR}

This is a simple summary of some of the main grammar points. Use it for revision. 


\section{SOURCES OF INFORMATION}

The bibliography and the addresses are provided to help you to get more information about England and English.

\section{SUPPLEMENTARY VOCABULARIES}

This part of the reference section groups together some of the more important words in English. Learn them if you have time.

Some are in the book. Others are not.

Remember that we all learn languages in different ways, so use this book in a way that suits you and the time you have got for study.

Rob Nolasco 